\title{
A new species of Raputia (Rutaceae) from the Selva Central of Peru
}

\author{
Robin Fernandez-Hilario', Robert Arteaga ${ }^{2}$ \\ I Herbario Forestal MOL, Facultad de Ciencias Forestales, Universidad Nacional Agraria La Molina, Av. La \\ Molina s/n, La Molina, Lima, Perú 2 Departamento de Ecología, Museo de Historia Natural "Javier Prado", \\ Universidad Nacional Mayor de San Marcos, Av. Arenales 1256, Jesús María, Lima, Perú \\ Corresponding author: Robin Fernandez-Hilario (rfernandez@lamolina.edu.pe)
}

Academic editor: M. Appelhans | Received 8 August 2017 | Accepted 16 October 2017 | Published 3 November 2017

Citation: Fernandez-Hilario R, Arteaga R (2017) A new species of Raputia (Rutaceae) from the Selva Central of Peru. PhytoKeys 89: 73-84. https://doi.org/10.3897/phytokeys.89.20136

\begin{abstract}
Raputia codo-pozuzoensis Rob. Fernandez \& Arteaga, sp. nov. (Galipeinae, Rutaceae), a new species endemic to the Huanuco region, in the Selva Central of Peru, is described and illustrated here. The new species differs from other species of Raputia by the combination of 5-7-foliolate leaves (a new characteristic for the genus) and longer petioles. A key to the four Peruvian species of Raputia is presented.
\end{abstract}

\section{Resumen}

Raputia codo-pozuzoensis Rob. Fernandez \& Arteaga, sp. nov. (Galipeinae, Rutaceae), una nueva especie endémica del departamento de Huánuco, en la Selva Central del Perú, es descrita e ilustrada aquí. La nueva especie difiere de las otras especies de Raputia por presentar hojas 5-7-folioladas (una nueva característica para el género) y peciolos largos. Una clave para las cuatro especies peruanas de Raputia es presentada.

\section{Keywords}

Raputia, Galipeinae, premontane forests, Neotropic

\section{Palabras clave}

Raputia, Galipeinae, Bosques premontanos, Neotrópico 


\section{Introduction}

Rutaceae Juss., in the order Sapindales (APG III, 2009; APG IV, 2016), is a family of mostly tropical and sub-tropical trees, shrubs, and aromatic herbs comprising approximately 2100 species in 154 genera (Kubitzki et al. 2011). In recent years, numerous phylogenetic studies have revealed that the seven sub-families initially proposed by Engler (1931) were paraphyletic (Chase et al. 1999, Scott et al. 2000, Groppo et al. 2008, Groppo et al. 2012, Morton and Telmer 2014), a revelation that has prompted recircumscription of intra-familial groups and new understanding of relationships among them. For example, at the subfamily level, Groppo et al. (2012) reduced the number of subfamilies to two, and Morton and Telmer (2014) to four; and at a more specific level, Bruniera et al. (2015), in the first study of relationships within subtribe Galipeinae (tribe Galipeeae, subfamily Rutoideae), where Raputia belongs, transferred all the species of Almeidea A. St.-Hil. to Conchocarpus J.C. Mikan and determined that the Galipeinae is apparently a monophyletic group.

Raputia and its type species Raputia aromatica were established by Aublet in 1775 based on collections from forest near the Orapu River in French Guiana. In the first comprehensive classifications of the Rutaceae, Engler $(1874,1931)$ recognized nine species in the genus, forming a group with heterogeneous characteristics.

Emmerich (1978) split this group and placed most of the species in three more homogenous genera (Neoraputia Emmerich, Sigmatanthus Huber ex Emmerich and Raputiarana Emmerich). Subsequently, Kallunki (1990) emended the description of Raputia and making three new combinations. Finally, the last published revision of the genus was made by Kallunki (1994), where she recognized 10 species. Currently, Raputia is found in the subtribe Galipeinae Kallunki [Angostura Alliance sensu Kubitzki et al. (2011)] along with 25 other genera, all restricted to the Neotropics, and characterized by tendencies toward zygomorphic flowers, a more or less tubular corolla, union of the filaments to a corolla tube, reduction in number of fertile stamens from five to two with the transformation of stamens into staminodes, modifications of anthers, loss of endosperm, a curved embryo and conduplicate and plicate cotyledons (Bruniera et al. 2015, Kallunki and Pirani 1997, Kubitzki et al. 2011). In addition, in most taxa with only two fertile stamens, the anthers are variously modified by basal or apical appendages or sterile basal portions above the point of attachment to the filament and, in some, the anthers or appendages are united (Kubitzki et al. 2011).

Brako and Zarucchi (1993), in the "Catalogue of the Flowering Plants and Gymnosperms of Peru", listed three species known from that country: Raputia ulei (K. Krause) Kallunki, Raputia heptaphylla Pittier and Raputia magnifica Engler. In the revision of the genus, Kallunki (1994) cited no specimens of Raputia ulei from Peru. Instead, she identified the collection (Vásquez et al. 8909) that was the basis for the report of that species from Peru (Brako and Zarucchi, 1993) as Raputia simulans Kallunki. Furthermore, she excluded Raputia heptaphylla and Raputia magnifica from the genus because they showed discordant characteristics and subsequently recognized them as Raputariana heptaphylla (Pittier) Kallunki (Jiménez 2014), and Neoraputia magnifica 
(Engl.) Emmerich ex Kallunki (Kallunki 2009), respectively. Additionally, Kallunki (1994) described Raputia megalantha Kallunki and transferred Achuaria hirsuta Gereau to Raputia hirsuta (Gereau) Kallunki, which with Raputia simulans Kallunki, are known from Peru (Vasquez and Rodriguez 2002; Ulloa Ulloa et al. 2004).

Raputia comprises a total of 11 Neotropical species, occurring from Venezuela and French Guiana to Amazonian Colombia, Peru and Brazil, principally from lowland areas, with shrubby or tree-like habit, opposite 1-3-foliolate leaves, circinate cauline monochasium, and pentamerous flowers with bilabiate corolla (Kallunki 1994; Kubitzki et al. 2011; Pirani 2005).

During fieldtrips to the premontane forests of Huanuco (Peru) in 2015, we collected an undescribed species of Raputia with 5-7-foliolate leaves, a new characteristic for the genus.

\section{Taxonomic treatment}

Raputia codo-pozuzoensis Rob. Fernandez \& Arteaga, sp. nov. urn:Isid:ipni.org:names:60475533-2

Figure 1-2

Diagnosis. Raputia codo-pozuzoensis differs from others species in this genus by its 5-7-foliolate leaves and longer petioles $(8.5-12.5 \mathrm{~cm}$ long).

Type. PERU. Huánuco: Prov. Puerto Inca, Dist. Codo de Pozuzo, alrededores de toma de agua cerca al Río Pozuzo, 565 m, 940'57.76"S, 75³0'31.35"W, 01 Feb 2015 (fl.), R. Fernandez, R. Arteaga \& F. Meza 830 (holotype MOL - 2 sheets).

Description. Monopodial shrub up to $2 \mathrm{~m}$ tall; stem cylindrical, $1-1.5 \mathrm{~cm}$ in diameter, lenticellate and finely ribbed, dark brown; the terminal buds, young twigs and petioles, and inflorescences pubescent, the hairs short and antrorse. Terminal twigs circular in transverse section, 4-7 $\mathrm{mm}$ in diameter, beige-colored when dry, lenticellate; terminal buds ferruginous, stipules absent. Leaves palmately compound, 5-7-foliolate, opposite or verticillate; petiole cylindrical, $8.5-12.5 \mathrm{~cm}$ long, $2-3 \mathrm{~mm}$ wide; petiolule absent; leaflet blades elliptical, acuminate at apex, decurrent at base, entire at margin, discolorous, sub-chartaceous, the venation brochidodromus, the surface pellucid-punctate, the upper and lower surface glabrous, midrib pubescent beneath, the hairs short and antrorse; central leaflet (21-) $25-36 \mathrm{~cm}$ long, $3.5-6 \mathrm{~cm}$ wide, the secondary veins (18-) 21-29; lateral leaflet progressively smaller, the basal ones (7.5-) $11-18 \mathrm{~cm}$ long, $1.7-3.5 \mathrm{~cm}$ wide, the secondary veins $10-16$. Inflorescence cauline, of 1-3 monochasia, with 6-14 flowers, $1.8-3 \mathrm{~cm}$ long including a peduncle $2-5 \mathrm{~mm}$ long. Flowers bisexual, zygomorphic, pentamerous; pedicel 1.5-2 mm long; flower buds slightly curved. Calyx $4-4.5 \mathrm{~mm}$ long, $3.5 \mathrm{~mm}$ wide at base of lobes, glabrous or pubescent; sepals fused at the base, 5-lobed, the lobes quincuncial, ovate, acute to obtuse at apex, $2 \mathrm{~mm}$ long, ciliate, pellucid-punctate. Corolla tubular, unequally 5-lobed, 12-17.5 mm long, bilabiate at anthesis, glabrous in the external surface, 


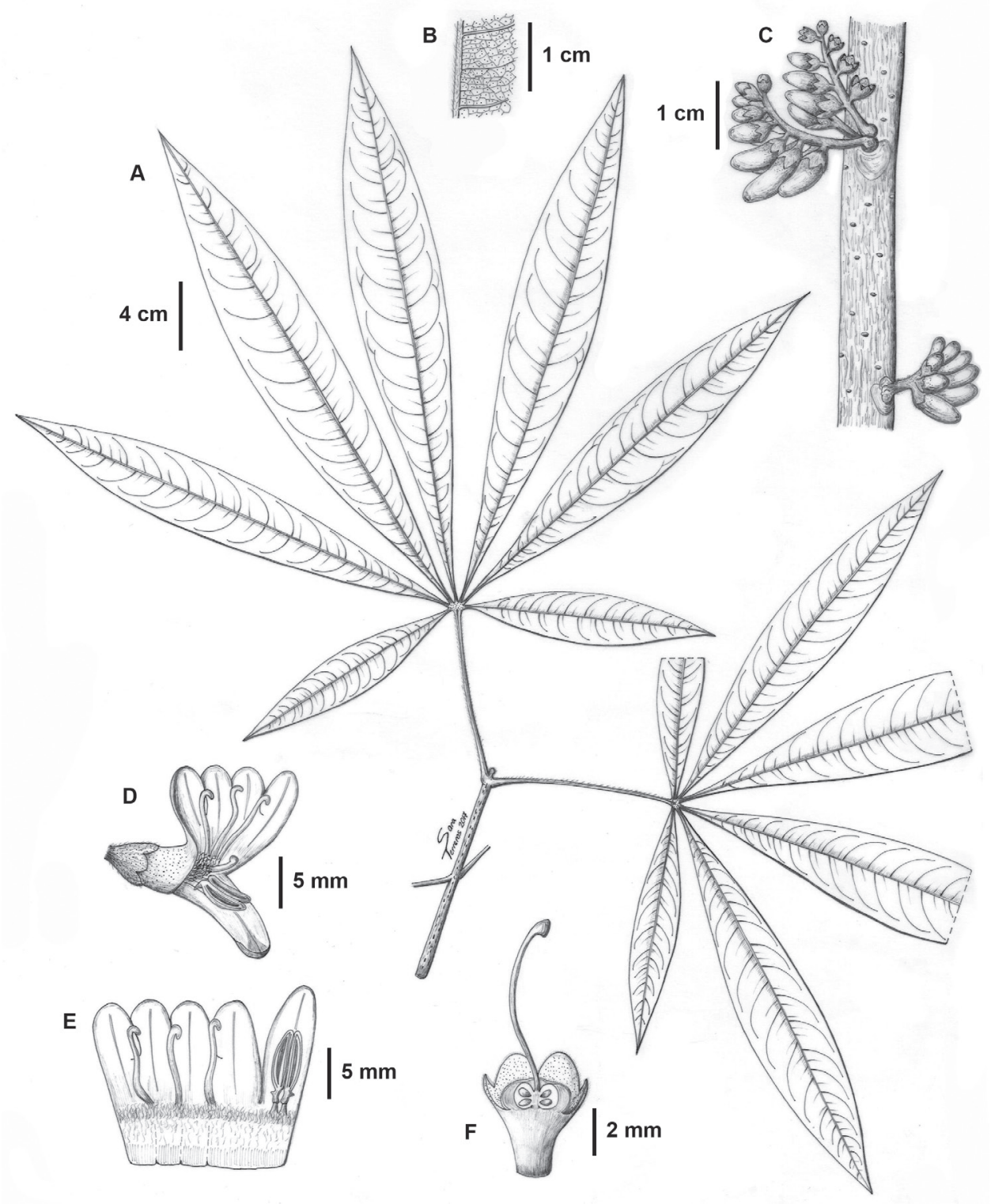

Figure I. Raputia codo-pozuzoensis. A Terminal twig B Midrib beneath and lower leaf surface C Inflorescences $\mathbf{D}$ Flower $\mathbf{E}$ Corolla opened showing two fertile stamens and staminodes $\mathbf{F}$ Longitudinal section of calyx, disc cupular, ovary and style. From R. Fernandez et al. 830 (MOL). Drawing by Sara Terreros.

sparsely pubescent in the inner base of the tube, woolly in the inner part of the throat, the trichomes ca. $1.2 \mathrm{~mm}$ long; the tube white to yellowish, 2-6 $\mathrm{mm}$ long to the sinuses of the innermost lobe (inferior lip), 6-9 $\mathrm{mm}$ long to the sinuses of the other 4 lobes (superior lip), recurved superior lip; the lobes green, imbricate, oblong, rounded at apex, the inner lobe $10-12 \mathrm{~mm}$ long, 3.5-5 mm wide, the other 4 lobes 5-6 mm 


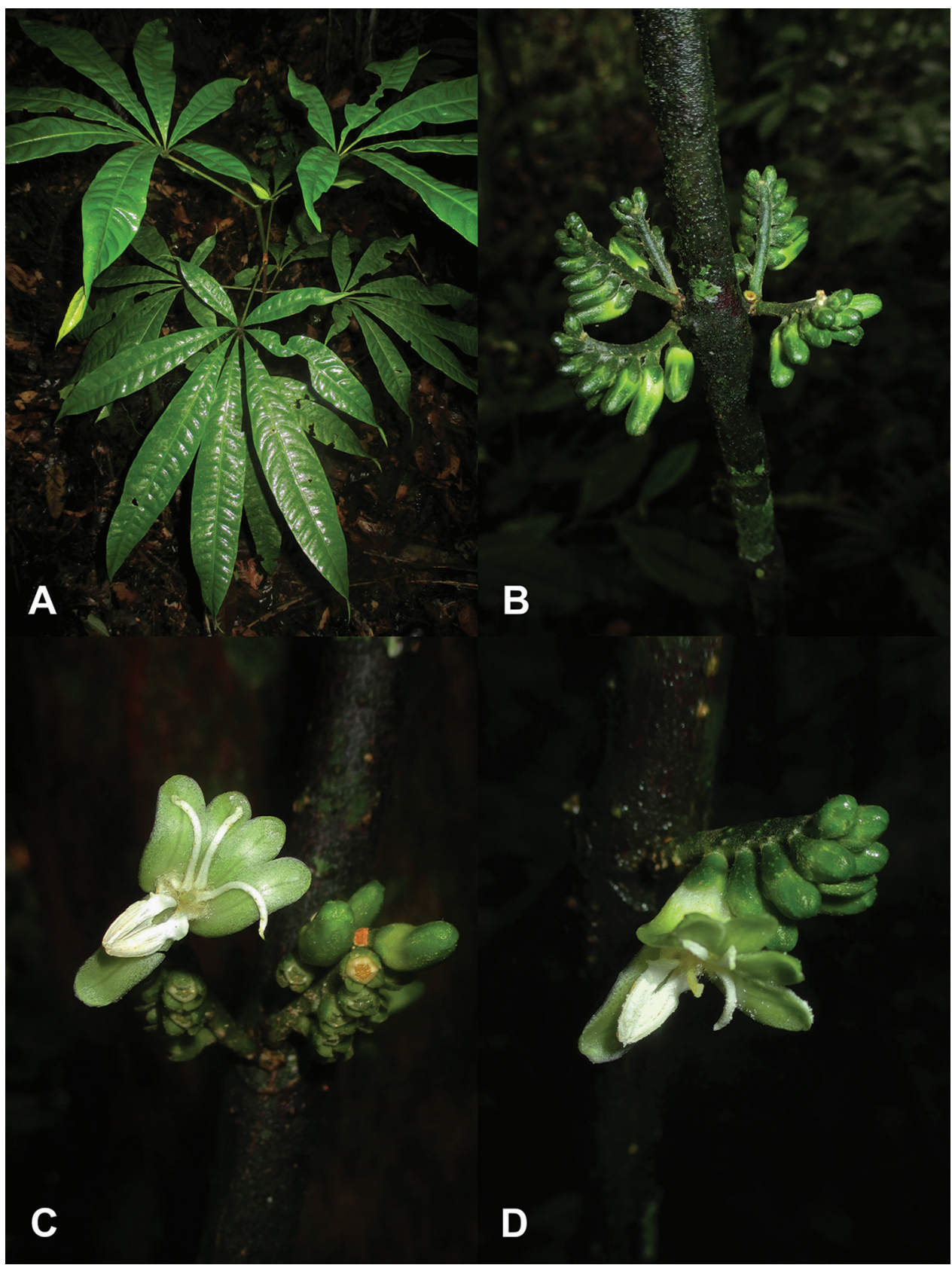

Figure 2. Raputia codo-pozuzoensis. A Habit B Inflorescence (R. Fernandez \& R. Arteaga 1079; MOL) C, D Flowers (R. Fernandez et al. 830; MOL). Photos by Robin Fernandez.

long, 3.5-4.5 mm wide, pellucid-punctate. Androecium of 2 fertile stamens and 3 staminodia, white-colored; filaments of fertile stamens flanking the inner lobe, adherent from the base to the throat of the corolla tube, the free portion above the throat ca. 2 
$\mathrm{mm}$ long; staminodia adherent from the base to the throat of the corolla tube, the free portion linear above the throat $9-11 \mathrm{~mm}$ long, alternate with the other four corolla lobes; filaments of fertile stamens and staminodia glabrous at the base and apex, only bearded at the throat of the corolla, filaments and back of anthers pellucid-punctate; anthers lanceolate, laterally coherent, basifixed, ca. $5.5 \mathrm{~mm}$ long, $1.5 \mathrm{~mm}$ wide, glabrous, the appendages flattened, ca. $1.5 \mathrm{~mm}$ long, $1 \mathrm{~mm}$ wide, glabrous. Gynoecium, ovary of 5 carpels united at the base and by single style, $1.5 \mathrm{~mm}$ in diameter, $1 \mathrm{~mm}$ high, furrowed, orange-colored; the style 10-11 mm long, slightly curved, glabrous, pellucid-punctate; the stigma $1 \mathrm{~mm}$ in diameter, slightly 5-lobed; disc cupular enveloping the ovary, $2.5 \mathrm{~mm}$ in diameter, $1.5 \mathrm{~mm}$ high, margin 5-lobed, cream-colored, glabrous. Fruit not seen.

Distribution and habitat. Raputia codo-pozuzoensis is endemic to humid premontane forest in central Peru, between 565-589 m.a.s.l., growing in zones with shallow to steep slopes in a loamy-silty soil. The only known population of this species occurs in the understory of a forest of tree species, such as: Chrysophyllum sanguinolentum (Pierre) Baehni, Helicostylis scabra (J.F. Macbr.) C.C. Berg, Hevea guianensis Aubl., Iryanthera hostmannii (Benth.) Warb., Mabea speciosa Müll. Arg., Macrolobium gracile Spruce ex Benth., Theobroma subincanum Mart. and Virola pavonis (A. DC.) A.C. Sm.

Etymology. The specific epithet refers to the Codo de Pozuzo district, the only place where the specimens were found and collected.

Phenology. Flowering take place from December to February.

Conservation state. We collected individuals of Raputia codo-pozuzoensis in areas of slightly disturbed forest, and we observed individuals sprouting after being cut for the establishment of "trochas" (pathways). We counted 20 individuals in an area of 0.5 ha. Thus, we assume that human activities are not affecting seriously the wild populations of this species. Nonetheless, in our inventories at other sites in Puerto Inca Province and surrounding areas, we and our collaborators have not observed other populations of this new species. Additionally, the extent of occurrence estimated of this species has been decreasing over the last years by deforestation and only remaining less than $100 \mathrm{~km}^{2}$ of the original forest cover. Therefore, under the guidelines of UICN (2012), we assign this species to the category Critically Endangered [CR (B1a+bi)].

Additional specimens examined. PERU. Huánuco: Prov. Puerto Inca, Dist. Codo de Pozuzo, alrededores de toma de agua cerca al Río Pozuzo, 589 m, 940'56.72"S, 75'30'30.85"W, 28 Dec 2015 (f.), R. Fernandez \& R. Arteaga 1079 (MOL), R. Fernandez \& R. Arteaga 1080 (USM), R. Fernandez \& R. Arteaga 1081 (HOXA).

Discussion. According to the morphologic analyses of Kubitzki et al. (2011), Raputia belongs to a natural group along with the following genera: Apocaulon R.S. Cowan, Decagonocarpus Engl., Ertela Adans., Lubaria Pittier, Ravenia Vell. and Raveniopsis Gleason, characterized by their opposite leaves (alternate in Apocaulon), overlapping sepals, connate petals, basally appendaged (exc. in Ertela) and often laterally coherent anthers, reticulate pollen grains, apocarpous gynoecia, and conduplicate, bilobed cotyledons. Among this group, the two herbaceous genera, Apocaulon and 


\begin{tabular}{|c|c|c|c|c|c|c|c|c|c|c|c|c|}
\hline |ֶ. & 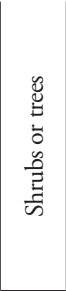 & 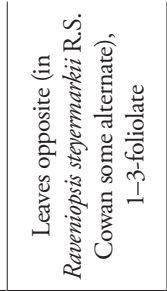 & 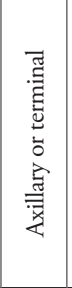 & 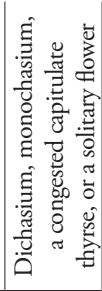 & 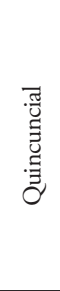 & 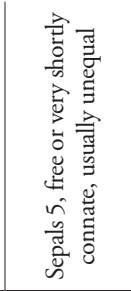 & 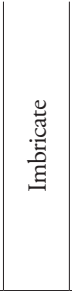 & 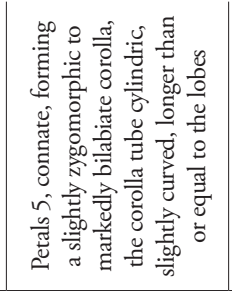 & 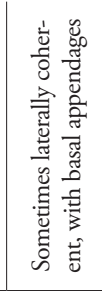 & 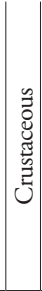 & 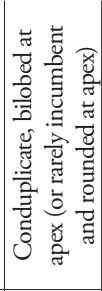 & $\curvearrowright$ \\
\hline | & 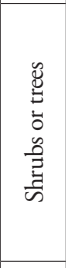 & 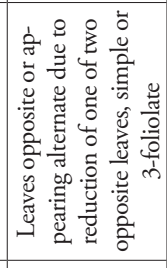 & 泴 & 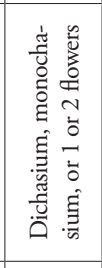 & $\begin{array}{l}\text { 氶 } \\
\text { 咅 } \\
\text { 急 }\end{array}$ & 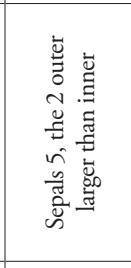 & 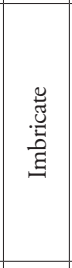 & 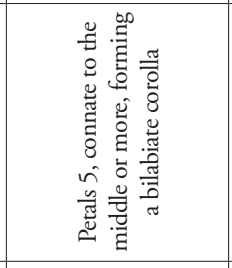 & 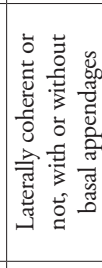 & & 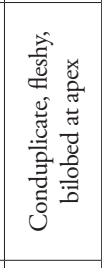 & $=$ \\
\hline | & 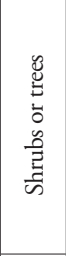 & 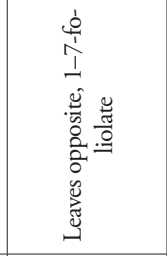 & 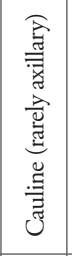 & 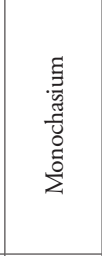 & 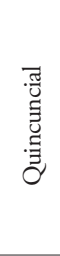 & 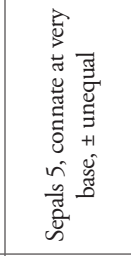 & 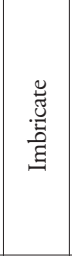 & 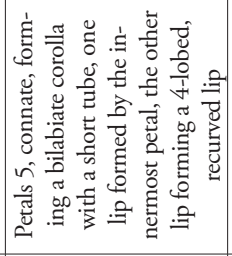 & 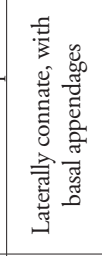 & : & 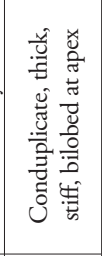 & $\approx$ \\
\hline | & $\stackrel{\mathscr{\varpi}}{\mathscr{H}}$ & 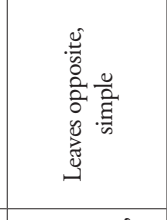 & 牢 & 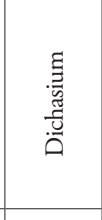 & 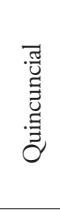 & 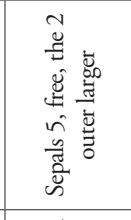 & 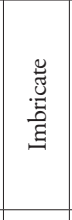 & 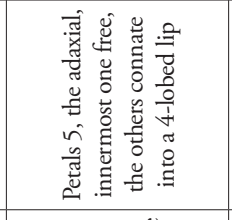 & 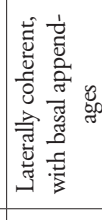 & 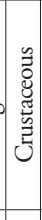 & 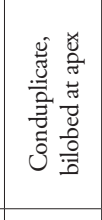 & - \\
\hline 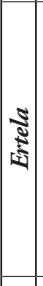 & 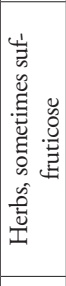 & 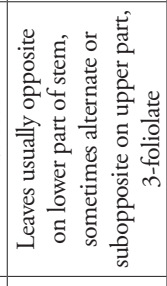 & 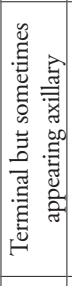 & 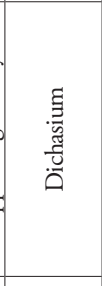 & 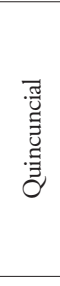 & 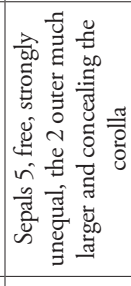 & 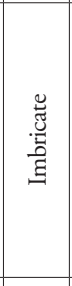 & 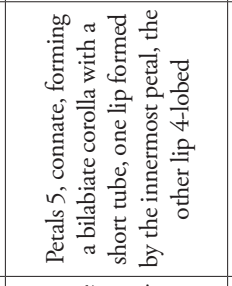 & 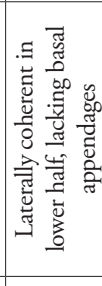 & & 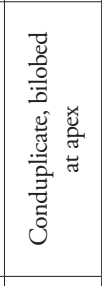 & $N$ \\
\hline | & 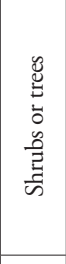 & 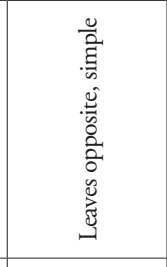 & 氶 & 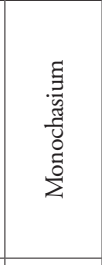 & 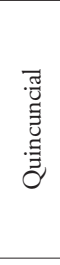 & 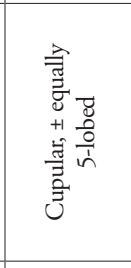 & 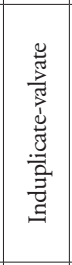 & 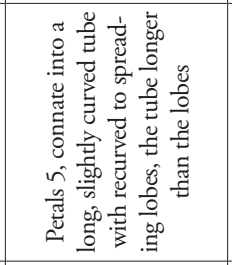 & 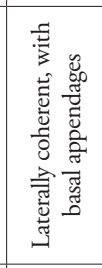 & 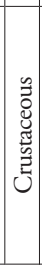 & 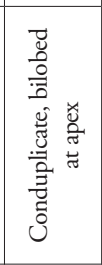 & $N$ \\
\hline $\begin{array}{l}\text { है } \\
\text { है } \\
\text { के }\end{array}$ & 萻 & 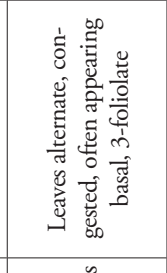 & 衰 & 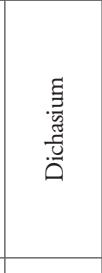 & $\begin{array}{l}5 \\
0 \\
0 \\
5 \\
5\end{array}$ & 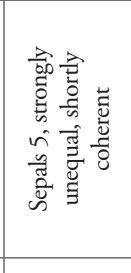 & 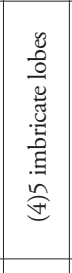 & 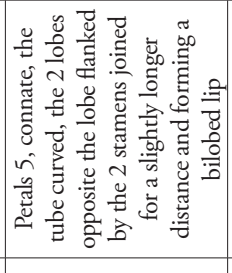 & 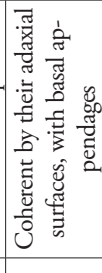 & 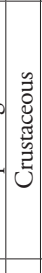 & 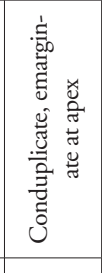 & - \\
\hline | & 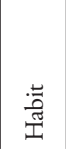 & 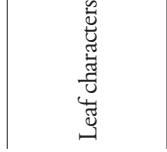 & 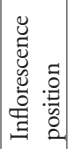 & 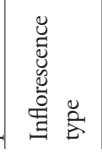 & 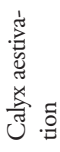 & 异 & 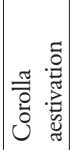 & 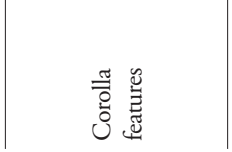 & 总 & & 总 & 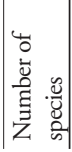 \\
\hline
\end{tabular}


Ertela, stand out and differ noticeably from the others. The former, by its alternate leaves and anthers coherent by their adaxial surfaces, and the later by its strongly unequal sepals, with the two outer much larger and concealing the corolla, and the anthers lacking basal appendages. Previously, Kallunki (1994) recognized that Raputia was related with the following genera: Decagonocarpus, Lubaria, Ravenia and Raveniopsis, forming a group characterized by opposite leaves, a quincuncial calyx (of which the margins are conspicuously overlapping at anthesis), and conduplicate, bilobed cotyledons. Kallunki (1994) differentiated Raputia from these other four genera by the presence of cauline inflorescences and the leathery testa (vs. terminal inflorescences and crustaceous testa). Even though we did not register neither the seeds nor the fruits of Raputia codo-pozuzoensis, the combination of characteristics such as cauline inflorescences, the petals connate, forming a bilabiate corolla with a short tube, and anthers laterally connate, with basal appendages, allow us to locate this new species in the Raputia genus. In Table 1 we display the different characteristics of genera related to Raputia, according to Kubitzki et al. (2011).

Raputia codo-pozuzoensis is easily distiguished from all other species of the genus by its 5-7-foliolate palmately compound leaves. The other three species found in Peru show unifoliolate (Raputia simulans) or three-foliolate leaves ( $R$. hirsuta and $R$. megalantha). Raputia codo-pozuzoensis differs further from $R$. simulans by its much shorter inflorescences 1.8-3 cm long (vs. 19.5-26.5 cm) and from Raputia hirsuta by its short and antrorse hairs (vs. hirsute) on stems, leaves, and inflorescences.

Like Raputia megalantha and Raputia maroana (R.S. Cowan) Kallunki, Raputia codo-pozuzoensis possesses inflorescences shorter than $6 \mathrm{~cm}$ and terminal leaflets longer than $20 \mathrm{~cm}$. Raputia codo-pozuzoensis differs, however, from $R$. megalantha by its petioles $8.5-12.5 \mathrm{~cm}$ long (vs. $0.8-3.3 \mathrm{~cm}$ ) and its corollas $12-17.5 \mathrm{~mm}$ long (vs. 30 $\mathrm{mm}$ ). Although Raputia codo-pozuzoensis shares with $R$. maroana petioles and corollas of similar lengths, it differs from the latter by its 5-7-foliolate (vs. 3-foliolate) leaves and filaments ca. $2 \mathrm{~mm}$ (vs. 11-12 mm) long. In addition, Raputia codo-pozuzoensis is restricted to premontane forest in southwestern Amazonia (Huanuco, Peru), whereas $R$. megalantha and $R$. maroana are distributed in lowland forests in northwestern Amazonia (Brazil, Peru, and Venezuela; Kallunki, 1994).

\section{Key to the species of Raputia in Peru}

$1 \quad 5-7$-foliolate leaves, petioles longer than $8 \mathrm{~cm}$ R. codo-pozuzoensis

- $\quad$ 1-3-foliolate leaves, petioles shorter than $4 \mathrm{~cm}$ 2

2 Leaves 1 -foliolate; inflorescences longer than $16 \mathrm{~cm}$; flowers more than $20 \ldots .$.

Leaves 3-foliolate; inflorescences shorter than $7 \mathrm{~cm}$; flowers fewer than $15 \ldots .3$

3 Central leaflet 8-30 cm long; inflorescences and petioles hirsute... $R$. hirsuta

- $\quad$ Central leaflet 50-71 cm long; inflorescences and petioles strigulose. 


\section{Additional Peruvian specimens of other species}

Raputia hirsuta. PERU. Loreto. Prov. Coronel Portillo, Padre Abad, granja del sr. Barrera, NE de la chacra de César Vela (Aguaytia), 17 Oct 1972, V. Schunke 5396 (F, MO, NY); Prov. Loreto, Río Tigre, San Jacinto, Campamento de Occidental Petroleum, 175-205 m, 02²8'S, 7547'W, 08 Jun 1993, H. Beltrán \& R. Foster 435 (F, USM); Prov. Loreto, Dist. Loreto, Pampa Hermosa and vicinity, $3^{\circ} 15^{\prime} \mathrm{S}, 75^{\circ} 50^{\prime} \mathrm{W}$, 03-20 Dec 1985, W. Lewis et al. 10328 (F, MO, USM), 04-09 Jun 1986, W. Lewis et al. 10729 (MO, USM), 04-09 Jun 1986, W. Lewis et al. 10782 (MO, USM); Prov. Loreto, Campamento Petrolero San Jacinto, Rio Tigre, $2^{\circ} 15^{\prime}$ S, $75^{\circ} 50^{\prime} \mathrm{W}, 16$ Sep 1979 , C. Díaz \& N. Jaramillo 1454 (MO); Prov. Mariscal Ramón Castilla, Margen izquierda del Río Yavari, entre Colonia Angamos y Lago Preto, 4³0'53"S, 7154'2.77"W, 10 Apr 2003, H. Beltrán et al. 5743 (AMAZ, USM); Prov. Mariscal Ramón Castilla, Alto Río Yaguas, tributario del Río Putumayo, aprox. $80 \mathrm{~km} \mathrm{NE}$ de Pebas, $140 \mathrm{~m}$, 0251'53.5"S, 71²4'54.1"W, 07 Aug 2003, M. Ríos et al. 537 (F); Prov. Maynas, Río Blanco, a 3 horas (Jonhson $40 \mathrm{Hp}$ ) desde Tamshiyacu, $130 \mathrm{~m}, 15$ Mar 1978, C. Díaz et al. 145 (MO); Prov. Requena, Sapuena, Jenaro Herrera, $170 \mathrm{~m}, 4^{\circ} 50^{\prime} \mathrm{S}, 73^{\circ} 45^{\prime} \mathrm{W}$, 12 Nov 1987, R. Vásquez et al. 9983 (MO, USM).

Raputia megalantha. PERU. Loreto. Prov. Maynas, Mishuyacu, near Iquitos, 100 m, Oct-Nov 1929, G. Klug 544 (F, NY, US); Prov. Maynas, Estación Biológica Rio Blanco, 04²0'S, 7245'W, 16 Sep 1985, R. Vásquez et al. 6743 (MO, NY); Prov. Maynas, Dist. Allpahuayo, Estación Experimental del IIAP, 0400'15"S, 732 $25^{\prime} 48^{\prime \prime} \mathrm{W}$, 30 May 1990, R. Vásquez et al. 13786 (MO, USM); Prov. Maynas, Dist. Iquitos, carretera del caserío de Puerto Almendras, 26 Jun 1984, M. Rimachi 7529 (US); Prov. Maynas, Dist. Iquitos, San Juan, km 31.5 carrera Iquitos-Nauta, $160 \mathrm{~m}, 3^{\circ} 59^{\prime} 34.7^{\prime \prime}$, 7326'42.5"W, 08 Sep 2002, M. Flores et al. 1690 (AMAZ, MO, USM); Prov. Maynas, Dist. Iquitos, Allapahuayo, Estación del IIAP, $150-180$ m, $04^{\circ} 10^{\prime} \mathrm{S}, 73^{\circ} 30^{\prime} \mathrm{W}, 18 \mathrm{Jun}$ 1991, R. Vásquez 16810 (AMAZ, MO, NY); Prov. Maynas, Dist. Iquitos, Allpahuayo, Estación Experimental del IIAP, 035' $16^{\circ} \mathrm{S}, 7^{\circ} 25^{\prime} 08^{\prime \prime W}, 11$ Oct 1990, $R$. Vásquez \& N. Jaramillo 14495 (MO); Prov. Maynas, Dist. San Juan, Reserva Nacional Allpahuayo-Mishana, $128 \mathrm{~m}, 03^{\circ} 58^{\prime} 02^{\prime \prime S}, 7^{\circ} 25^{\prime} 08^{\prime \prime W}, 19$ Nov 2008, R. Vásquez et al. 35060 (HOXA). San Martín. Prov. Lamas, Caserio Bonilla, trail to E of road, Km 75 of Tarapoto-Yurimaguas road, $250 \mathrm{~m}, 6^{\circ} 16^{\prime} \mathrm{S}, 76^{\circ} 17^{\prime} \mathrm{W}, 20$ Apr 1986, S. Knapp \& J. Mallet 7138 (USM, MO, NY); Prov. Lamas, Santa Rosa de Davidcillo, trail to E of road to Tioyacu, $200 \mathrm{~m}, 6^{\circ} 16^{\prime} \mathrm{S}, 76^{\circ} 17^{\prime} \mathrm{W}, 22-23$ Apr 1986, S. Knapp \& J. Mallet 7162 (USM, MO, NY); Prov. Lamas, Santa Rosa de Davidcillo, $220 \mathrm{~m}, 6^{\circ} 15^{\prime} \mathrm{S}, 76^{\circ} 17^{\prime} \mathrm{W}, 21$ Aug 1986, S. Knapp 8109 (MO, USM).

Raputia simulans. PERU. Loreto. Prov. Mariscal Ramón Castilla, cabeceras del Río Apayacu, Noroeste de Pebas, 150 m, 0307'00"S, 7242'43"W, 17 Aug 2003, M. Ríos et al. 680 (F, NY); Prov. Maynas, Dist. Iquitos, Quebrada Aucaya, trocha de la cooperativa, 11 Aug 1973, S. McDaniel \& M. Rimachi 17701 (MO, NY); Prov. Maynas, Dist. Iquitos, Nina rumi-Rio Nanay, 122 m, 03ํ8' $\mathrm{S}, 73^{\circ} 25^{\prime} \mathrm{W}, 05$ Mar 1987, R. Vásquez et al. 8909 (MO, NY); Prov. Maynas, Dist. Iquitos, Estación Experimental 


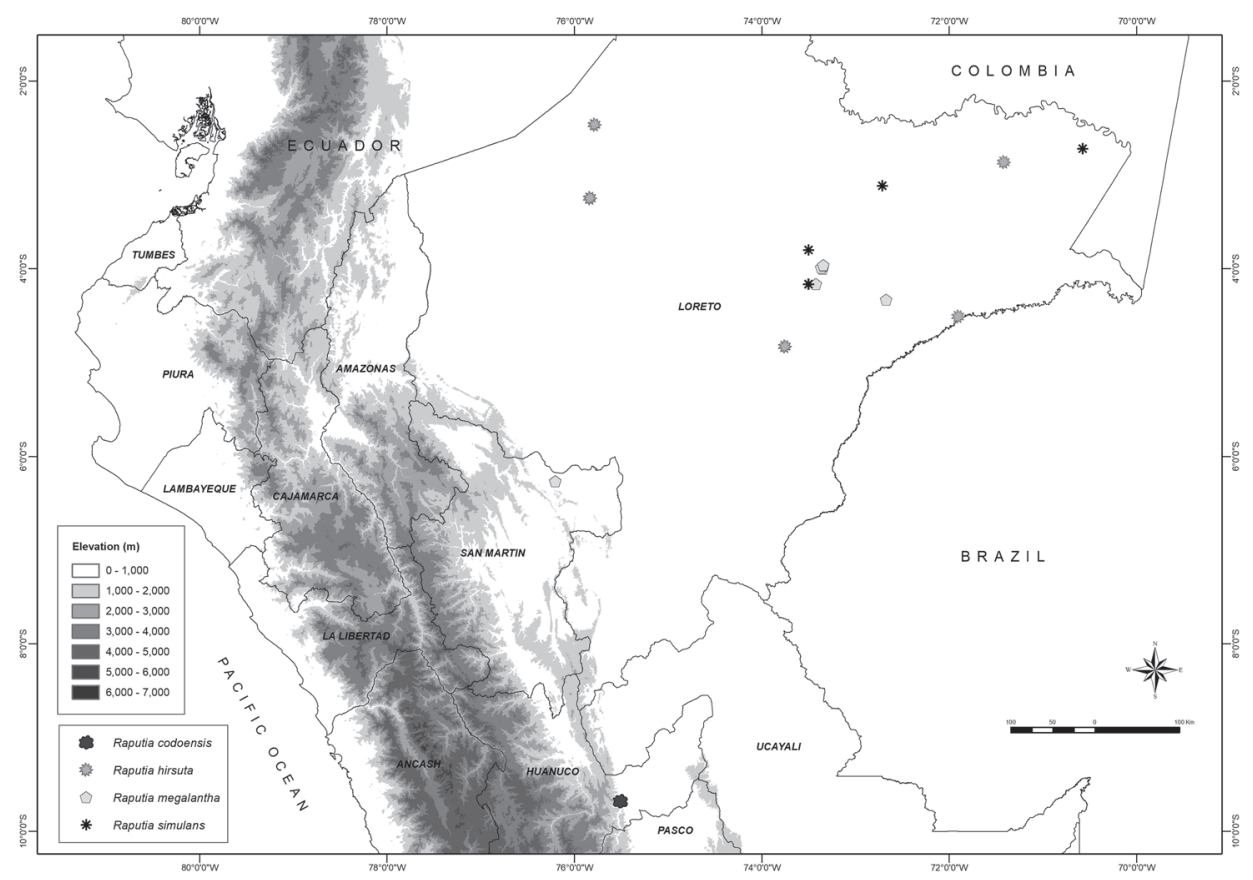

Figure 3. Distribution of Raputia species in Peru.

del IIAP, 04 Nov 1990, R. Vásquez \& $N$. Jaramillo 14560 (MO, NY), 150-180 m, $04^{\circ} 10^{\prime} \mathrm{S}, 73^{\circ} 30^{\prime} \mathrm{W}$, Nov 1990, $R$. Vásquez \& $N$. Jaramillo 14626 (MO), 24 May 1991, $R$. Vásquez \& N. Jaramillo 16426 (MO); Prov. Maynas, Dist. Iquitos, Allpahuayo, 150 m, 0410'S, 73³0'W, 19 Mar 1992, R. Vásquez 17727 (MO); Prov. Maynas, Dist. Iquitos, carretera Iquitos-Nauta, km 28, trocha del Fundo Pichiri, 150 m, 23 Jul 1997 , M. Rimachi 12005 (USM); Prov. Maynas, Dist. Putumayo, NE de Iquitos y Pebas, en la esquina del trapezoide de Colombia, $80 \mathrm{~m}, 02^{\circ} 43^{\prime} 15.9^{\prime \prime S}, 70^{\circ} 34^{\prime} 30.6^{\prime \prime W}, 28$ Oct 2010, I. Huamantupa et al. 14752 (F).

\section{Acknowledgements}

This research has been developed as part of the biological monitoring program of the 2D seismic project of Petrolifera Petroleum of Peru, company of the Gran Tierra group. We express our sincere gratitude to Pacific PIR for the logistical facilities in the field and Jacquelyn A. Kallunki for her support and comments during the drafting of this manuscript. The curators from the AMAZ, HOXA and USM herbaria are gratefully acknowledged for their logistical support during the review of botanical material. We also thank Sara Terreros for the excellent illustration and Andrea Bravo for the distribution map, as well as Kenneth J. Wurdack and Carla P. Bruniera for their valuable feedback on the manuscript. 


\section{References}

Albuquerque B (1976) Revisão Taxonômica das Rutaceae do Estado do Amazonas. Acta Amazônica 6(3, suplemento): 1-67.

APG (2009) An update of the Angiosperm Phylogeny Group classification for the orders and families of flowering plants: APG III. Botanical Journal of the Linnean Society 161(2): 105-121. https://doi.org/10.1111/j.1095-8339.2009.00996.x

APG (2016) An update of the Angiosperm Phylogeny Group classification for the orders and families of flowering plants: APG IV. Botanical Journal of the Linnean Society 181(1): 1-20. https://doi.org/10.1111/boj.12385

Aublet F (1775) Histoire des Plantes de la Guiane Françoise Vol. 2. Pierre-François Didot. London \& Paris, 670-673. https://doi.org/10.5962/bhl.title.674

Brako L, Zarucchi J (1993) Catalogue of the Flowering Plants and Gymnosperms of Peru. Monographs in Systematic Botany from the Missouri Botanical Garden 45: 1-1286.

Bruniera CP, Kallunki JA, Groppo M (2015) Almeidea A. St.-Hil. belongs to Conchocarpus J.C. Mikan (Galipeinae, Rutaceae): evidence from morphological and molecular data, with a first analysis of subtribe Galipeinae. PLoS ONE 10(5): 1-20. https://doi.org/10.1371/ journal.pone.0125650

Chase MW, Morton C, Kallunki JA (1999) Phylogenetic relationships of Rutaceae: A cladistic analysis of the subfamilies using evidence from $\mathrm{rbcL}$ and atpB sequence variations. American Journal of Botany 86(8): 1191-1199. https://doi.org/10.2307/2656983

Emmerich M (1978) Contribuição ao conhecimento da tribo Cusparineae [sic] (Rutaceae). Nova conceituação de Raputia e gêneros derivados. Rodriguêsia 30(45): 223-307.

Engler A (1874) Rutaceae. In: Martius CFP, Eichler AG (Eds) Flora Brasiliensis 12(2). 77-196. https://doi.org/10.5962/bhl.title.454

Engler A (1931) Rutaceae. In: Engler A, Prantl K (Eds) Die natiirlichen Pflanzenfamilien (2 ${ }^{\text {nd }}$ edn, T. 19a). Wilhelm Engelmann, Leipzig, 187-359.

Groppo M, Kallunki JA, Pirani JR, Antonelli A (2012) Chilean Pitavia more closely related to Oceania and Old World Rutaceae than to Neotropical groups: evidence from two cpDNA non-coding regions, with a new subfamilial classification of the family. PhytoKeys 19: 9-29. https://doi.org/10.3897/phytokeys.19.3912

Groppo, M, Pirani JR, Salatino MLF, Blanco SR, Kallunki JA (2008) Phylogeny of Rutaceae based on two noncoding regions from cpDNA. American Journal of Botany 95(8): 985-1005. https://doi.org/10.3732/ajb.2007313

Jiménez Q (2014) Rutaceae. In: Hammel BE, Grayum MH, Herrera C, Zamora N (Eds) Manual de Plantas de Costa Rica, Volumen VII. Monographs in Systematic Botany from the Missouri Botanical Garden 129: 780-814.

Kallunki JA (1990) An emended description of and new combinations in Raputia (Cuspariinae, Rutaceae). Brittonia 42(3): 175-177. https://doi.org/10.2307/2807208

Kallunki JA (1994) Revision of Raputia Aubl. (Cuspariinae, Rutaceae). Brittonia 46(4): 279-295. https://doi.org/10.2307/2806910

Kallunki JA (2005) Rutaceae. In: Steyermark JA, Berry PE, Yatskievych K, Holst BK (Eds) Flora of the Venezuelan Guayana, Volume 9 (Rutaceae-Zygophyllaceae). 1-38. 
Kallunki JA (2009) Validation of Neoraputia (Galipeae, Rutaceae) and description of two new species from Eastern Brazil. Brittonia 61(1): 28-34. https://doi.org/10.1007/s12228-0089054-8

Kubitzki K, Kallunki JA, Duretto D, Wilson PG (2011) Rutaceae. In: Kubitzki K (Ed.) The families and genera of vascular plants, Vol. X: Flowering Plants: Eudicots (Sapindales, Cucurbitales, Myrtaceae). Springer, Berlin, 276-356.

Morton CM, Telmer C (2014) New subfamily classification for the Rutaceae. Annals of the Missouri Botanical Garden 99(4): 620-641. https://doi.org/10.3417/2010034

Pirani JR (2005) Flora da Reserva Ducke, Amazonas, Brasil: Rutaceae. Rodriguêsia 56(86): 189-204. http://rodriguesia.jbrj.gov.br/FASCICULOS/Rodrig56_86/02_12_rutaceae.pdf

Scott KD, McIntyre CL, Playford J (2000) Molecular analyses suggest a need for a significant rearrangement of Rutaceae subfamilies and a minor reassessment of species relationships within Flindersia. Plant Systematics and Evolution 223: 15-27. https://doi.org/10.1007/ BF00985324

IUCN (2012) Categorías y Criterios de la Lista Roja de la UICN: Versión 3.1. Segunda edición. Gland, Suiza y Cambridge, Reino Unido, 1-34.

Ulloa Ulloa C, Zarucchi J, León B (2004) Diez años de adiciones a la flora del Perú: 1993-2003. Arnaldoa Número Especial, 1-242.

Vásquez R, Rodríguez E (2002) Adiciones a la Flora Peruana: especies nuevas, nuevos registros y estados taxonómicos de las Angiospermas para el Perú. Arnaldoa 9(2): 43-110. 